\title{
Financial Performance of the Lebanese Bank
}

\author{
Hiyam Sujud $^{1} \&$ Joyce Tannous ${ }^{2}$ \\ ${ }^{1}$ Finance Department, Faculty of Business, Lebanese University, Lebanon \\ ${ }^{2}$ Senior Auditor at DFK, Fiduciaire du Moyen Orient \\ Correspondence: Hiyam Sujud, Finance Department, Faculty of Business, Lebanese University, $1^{\text {st }}$ Branch, \\ Lebanon. E-mail: hiyamsujud @ hotmail.com
}

Received: August 21, 2020

Accepted: October 1, 2020

Online Published: October 20, 2020

doi:10.5539/ijef.v12n11p66

URL: https://doi.org/10.5539/ijef.v12n11p66

\begin{abstract}
Lebanese Banks financial performance is an important topic especially that the performance of banks has a significant influence on the economy. A study on the Lebanese Banks' financial performance determinants is essential in order to provide banks with indicators that can help them to enhance and improve their performance. The purpose of this study is to determine and analyze the determinants or the factors affecting the profitability of the Lebanese Banking Sector. The sample studied consists of the Lebanese Banking Sector including all banks, but limited to a period of 19 years being from 1999 till 2017. Results of the study were analyzed using the statistical program "SPSS". Findings revealed the significance relation each of Capital adequacy, efficiency, and growth in loans toward banks profitability as well as the significance relation between Inflation GDP deflator rate, Real Interest Rate and profitability. At the same time, no significant relation was obtained between liquidity, GDP growth and profitability.
\end{abstract}

The study recommends banks to enhance their internal factors being the most important determinants of banks profitability, especially their capital adequacy and loan growth.

Keywords: assets quality, capital adequacy, external factors, efficiency, financial performance, GDP growth, internal factors, inflation GDP deflator rate, loan growth, liquidity, profitability, real interest rate

\section{Introduction}

\subsection{Introduce the Problem}

One of the major important sectors in Lebanon is the banking sector, due to its significant role in the economy of the country.

The most important concept for banks and financial institutions is profitability. Performance of banks is expressed by many factors including: efficiency, productivity and profitability.

The financial system equilibrium and stability is based on the good performance of financial institutions. Thus, the profitability of financial institutions, especially the banking sector is one of the most significant issues.

The priorities of the public and private sector banking institutions in the economic environment are the achievement of good performance and efficiency as well as the improvement of profitability. These objectives are achieved by banks through the improvement of competitiveness, delivering better quality of service, and the costs reduction. In order to improve profitability banks must understand what the determinants of profitability are and how to be able to improve these determinants.

Various studies have defined profitability. Despite the profitability indicators, various studies on the banking sector noticed that capital ratio, expense control \& loans growth are necessary factors for higher profitability achievement.

This study evaluates the performance of the Lebanese Banking Sector in terms of "Return on Equity" \& "Return on Assets" for the period 1999-2017 using the following internal banks factors: Capital Adequacy Ratio, Cost-to-Income Ratio, Liquidity Ratio and Growth in Loans percentage. Furthermore, the study analyzed the effect of these factors in the presence of other external factors such as: Year, GDP growth, Inflation GDP Deflator and Real Interest Rate. For that purpose, data related to internal factors was collected from "Bank Data" that provides the annual reports and the performance highlights of the Lebanese banking sector throughout the years 
(including all Lebanese banks), while data related to the external factors was collected from "World Bank" that provides the macroeconomic factors for all years and all countries.

\subsection{Problem Statement}

The growth of the economy can be determined by the banking sector financial performance and the main common indicator of bank performance is profitability.

Return on Assets \& Return on Equity were mentioned always as the main factors that characterize the banks' profitability. The research conducted before on banks' profitability highlighted on the internal and external factors affecting the banks' profitability.

Banks' internal factors are the internal determinants of banks' profitability such as: Capital Adequacy Ratio, Cost-to-Income Ratio, Liquidity Ratio and Growth in loans. While external factors are macroeconomic factors such as GDP, inflation rate, interest rate and others.

The main research problem of this study is to examine the effect of the banks' internal factors on the profitability of the Lebanese Banking Sector among the years. However, after the validation of this research problem, some external factors were added to enhance the models generated for profitability.

\subsection{Objectives of the Study}

In general, despite the objective of this study to determine the factors affecting the financial performance of the Lebanese Banking Sector, the main goal fall towards testing the internal banks' indicators and whether they will be significant on the profitability of Lebanese Banks. The aim of this study is detailed below:

- To determine whether a relationship exists between the banks' internal factors and the profitability in terms of Return on Assets "ROA" and Return on Equity "ROE".

- To measure profitability, capital adequacy, liquidity, efficiency and loans of Lebanese banks.

- To analyze the financial performance of Lebanese Banks among the years.

- To measure descriptive statistics.

- To determine the overall relationship between banks' profitability and internal factors.

- To know the conditions of an overall good financial performance.

- To assess the determinants of banks' profitability in case of intervention of external factors.

\subsection{Research Question}

Through this research, we will cover and discuss a theoretical framework complied by a case study about the factors affecting Lebanese banks profitability. The research questions are:

1) Is there any relationship between the banks' internal factors and their profitability?

2) In case of intervention of external factors what will be the determinants of banks profitability?

\subsection{Research Hypotheses}

For a better understanding of the research targets and for suitable exploration of the research question, the following hypotheses are stated:

Hypothesis 1 (H1): there is a positive relationship between capital adequacy and banks profitability (ROA \& ROE).

Hypothesis 2 (H2): there is a negative relationship between efficiency and banks profitability (ROA \& ROE).

Hypothesis $3(\mathrm{H3})$ : there is a positive relationship between growth in loans and banks profitability (ROA \& ROE).

Hypothesis 4 (H4): there is negative relationship between liquidity and banks profitability (ROA \& ROE).

We note that an intervention of 4 external variables was applied to our study to enhance the model built, but was not tested as a hypothesis. The main hypothesizes tested are illustrated above.

\subsection{Significance of the Study}

The study worked towards establishing the factors responsible for Lebanese Banks performance.

Insights on the factors that determine banks performance are provided by this study for banks owners and policy makers.

Therefore, this study contributed to more understanding of the indicators having impact on Lebanese Banks 
financial performance and profitability. Lebanese banks must understand the factors that have good impact on their performance and work to enhance these factors, thus leading to a more effective, productive and competitive banking sector.

In general, the study contributes to highlight on the important factors affecting banks performance and serves as a basis to provide measure for shareholders and stakeholders as well as knowledge for banks to enhance their performance.

\subsection{Scope of the Study}

The study about the influencing indicators of banks profitability focused on the performance of the Lebanese banks purposely to establish the main internal factors for these banks performance.

The scope of this study includes all Lebanese banks (59 banks) and is limited to time period of 1999 to 2017. Several internal factors are taken into consideration but restricted to those influencing banks' profitability.

\subsection{Literature Review}

A number of studies were conducted on what affects banks profitability. In this section, we will synthesize the determinants of banks profitability based on the results of previous researches.

Despite different authors' opinion on the determinants of banks profitability, they all agree that the determinants of profitability can be internal and external.

\subsubsection{Literature Review on Internal Determinants of Profitability}

The studies conducted by Bourke (1989), Demirguc-Kunt and Huizinga (1999), Pasiouras and Kosmidou (2007), Ben and Goaied (2008) and Kosmidou (2008), revealed that banks with higher capital adequacy ratio get higher profitability. Higher level of equity to total assets leads to high profitable banks.

This was also supported with an empirical study conducted by A and Huizinga (1999), Ben and Goaied (2008), and Kosmidou (2008). The results of the study showed that higher level of equity to total assets lead to high profitable banks.

A significant positive relationship exists between capital adequacy and bank profitability as per Bourke (1989).

In addition to the above studies, a study on the determinants of profitability of some national banks in Kuwait for the period 1993-2005 was conducted by Al-Mutairi and Al-Omar (2008). The results showed a direct relationship between return on assets (ROA) and the equity and total assets of banks; in contrast, an insignificant or a non-existing relationship between profitability and loans.

In Pakistan, an empirical research was conducted by Javaid et al. (2011). The sample studied included 10 banks for the period from 2004 till 2018. The author studied the relation of internal factors on profitability by using the OLS method. The results generated a conclusion on the relationship between profitability and total assets, debts, total equity and total deposits as well as loans. As per Javaid et al. (2011), loans do not have an impact on profitability while as a significant impact exists by deposits and equity on profitability.

Schiniotakis (2012) study showed that profit is strongly influenced by the bank capitalization.

Ani, Ugwunta, Ezeudu, and Ugwuanyi (2012) studied through the Pooled Ordinary Least Square method banks profitability in Nigeria. The sample studied included 15 banks and the period covered is from 2001 to 2010 . The results showed that it there is insignificant relation between total assets and profitability; while profitability is significantly affected by the capital adequacy, debts to total assets and deposits.

All the above studies were mainly concentrated on the impact of capital adequacy on profitability. However, some studies and researches conducted focused on the effect of liquidity on banks' profitability. Some of the results are presented below:

According to Pasiouras and Kosmidou (2007) as well as Molyneux and G. (1992) and Guru (2002), a negative relationship exists between liquidity and profitability.

Other studies conducted on the effect of liquidity on profitability in Malaysia and China concluded that no significant relationship exists between liquidity and profitability.

Also, in the late 1980s and mid 1990s studies were conducted on European banks by Molyneux and Thornton (1992) and Goddard et al. (2004) and they found that a negative relationship exists between liquidity and profitability.

In Saudi Arabia a correlation and regression analysis was performed by Eljely (2004) and concluded a negative relationship between liquidity and profitability. 
An empirical study was also performed on banks by Pimentel et al. (2005) in Brazilian market and the results showed that profitability and liquidity are negatively correlated.

In fact, different authors have found different relationships and correlation between the liquidity and profitability. For example, a study was conducted in Ghana by Lartey, Antwi1, and Boadi (2013) on the effects of liquidity on banks profitability, and the study revealed a weak positive relationship between the two variables.

The effect of liquidity on profitability was studied from a sample of Canadian banks and banks in US. The study was conducted by Bordeleau, Crawford, and Graham (2009). The results showed there is no linear relationship between liquidity and profitability.

Other Authors studied the effect of efficiency the profitability. One of the ratios used to measure efficiency is the cost to income ratio. As per Francis (2004) and Ghosh et al. (2003), the relationship between cost to income ratio and profitability is negative.

Previous studied conducted by several authors (Alexiou \& Sofoklis, 2009; Athanasoglou et al., 2008; Dietrich \& Wanzenried, 2011; García-Herrero et al., 2009; and Pasiouras \& Kosmidou, 2007, among others) concluded that there is a high significant relationship between efficiency and profitability.

As per Berger (1995), banks and financial institutions are able to generate more profit when they have efficiency in operation and resources management.

In fact, several and different studies were conducted on the effect of internal factors on banks' profitability indicating that there is a significant relationship between profitability and capital adequacy, assets quality, efficiency, and loans while a negative relation exists between profitability and liquidity.

Moving on to external factors, studies conducted included several factors such as GDP Growth, Real Interest Rate, Inflation Rate and others. We will present below the previous studies conducted on external factors and their results.

\subsubsection{Literature Review on External or Macroeconomic Determinants of Profitability}

Several studies were conducted in various countries.

In Banglasesh, the study conducted on banking sector profitability revealed that a significant relationship exists between inflation and profitability while a significant but negative relationship exists between economic growth and profitability. This study was conducted by Sufian and Kamarudin (2012) who selected a sample of 31 banks over a period of 11 years (From 2000 to 2010).

Another study was conducted by Rao and Lakew (2012) but the scope of this study was the banking sector in Euthiopia from 1999 till 2008. The study indicated that inflation and GDP Growth are insignificant despite their positive relation with profitability.

A study on the profitability of Switzerland commercial banks was conducted by Dietrich and Wanzenried (2009) for the period from 1999 till 2006. The study covered a large sample of observations and banks (919 observations and 453 banks). They used the regression analysis to determine the effect of macroeconomic factors on profitability. The results of their study indicated that the profitability is significantly and positively affected by GDP growth.

Study on profitability of banks conducted in South Easter Europe, for a period of 1998-2002 revealed that there is a significant and positive relationship between inflation and profitability.

Ongore (2013) conducted also a study on the effect of macroeconomic variables on banks profitability in Kenya. The method used was the linear multiple regression. The results of his study showed that GDP has an insignificant correlation coefficient with ROA being -0.046 and inflation has a relation affecting significantly and negatively profitability (Coefficient of correlation -0.055 ).

Zeitun (2012) studied the effect of macroeconomic factors on profitability for the banking sector in Gulf Cooperation countries. His study proved that there is positive relation between GDP and profitability while a negative relation exists between inflation and profitability.

Our study comprise a mix of internal and external factors, to determine which are the factors influencing Lebanese banks profitability.

\section{Conceptual Framework}

The definition of the conceptual framework is: a combination of general thoughts and codes obtained from related enquiries and used to prepare a successive presentation. Independent variable is defined as a variable that 
is supposed to affect or influence a dependent one. Its value doesn't contribute or represent a problem that requires explanation on the analysis; however this variable can be changed once it is required. The independent variables in the study were bank specific variables enhancing banks' performance. The dependent variable was profitability of Lebanese banks in terms of RAO \& ROE.

Independent Variables

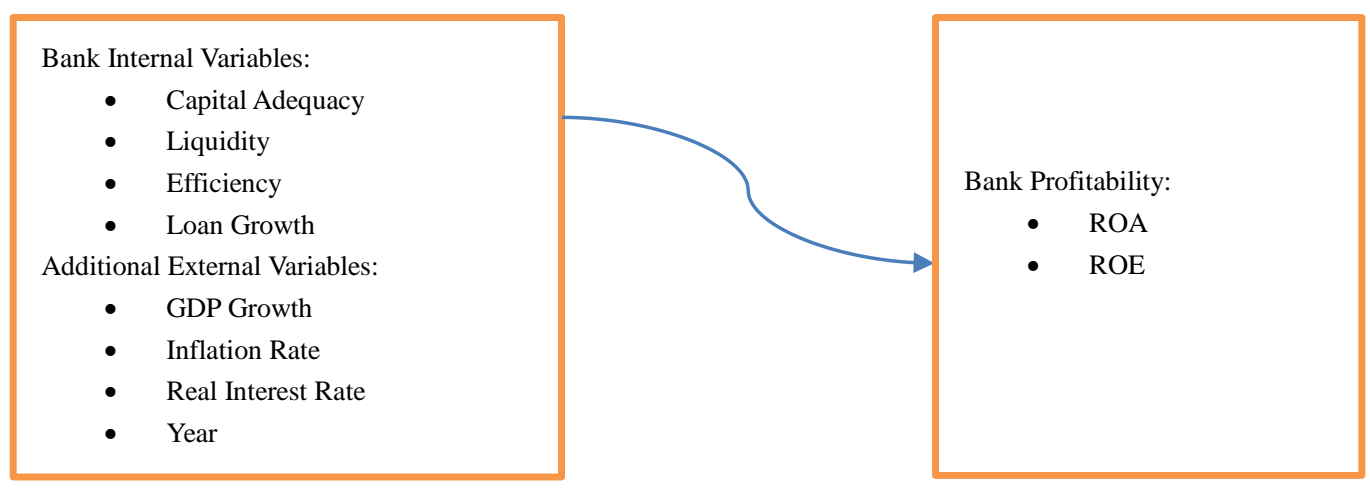

\subsection{Operationalization of Variables}

The various study variables were operationalized as shown on Table 1:

Table 1. Variables operationalization

\begin{tabular}{ccc}
\hline Variables & Measurement & Symbol \\
\hline Financial Performance & Income/Equity & ROE \\
ROA \\
Capital Adequacy & Income/Assets & Capital_Adequacy \\
Efficiency & Total Equity/Total Assets & Cost_Income \\
Loan Growth & Cost/Income & Loan_Growth \\
Liquidity & Loans Y2-Loans Y1/Loans Y1 & Liquidity \\
GDP Growth & Liquid assets/deposits & GDP_Growth \\
Inflation GDP Deflator Rate & (GDP in year 2/ GDP in year 1) - 1 & Inflation_GDP_Def \\
Real Interest Rate & (Nominal GDP/Real GDP)*100 & Real_IR \\
Year & Nominal Interest Rate-Inflation Rate & Year \\
\hline
\end{tabular}

\section{Methodology}

\subsection{Data Collection}

Data for all banks in Lebanon was collected from "Bank data" for the period 1999-2017. The data collected includes the ratios used for measuring banks profitability.

Data on macroeconomic factors for the period 1999-2017 related to Lebanon were also collected from the "World Bank" website, analyzed, edited, coded and cleaned through Microsoft Excel.

\subsection{Research Design}

\subsubsection{Sample Size}

As mentioned in the previous paragraph, the data for the Lebanese banking sector included all banks in Lebanon; however the observations were restricted to 19 years (quarterly observation) being from 1999 till 2017.

\subsubsection{Data Analysis Techniques}

All the below techniques were performed using SPSS Statistics:

- Descriptive statistics were used to analyze the banks' indicators among years, as well as scatter plots were generated for dependent and independent variables to assess the relationship between them.

- A test for correlation between variables was performed to measure how much the change in one variable predicts the change in another one. 
- When variables are positively linked, if the value of one variable increases, the value of the other also increases.

- In contrast, when variables are adversely interrelated, if the value of one variable increases, the value of the second one will decrease.

- In the correlation analysis, a correlation coefficient is estimated and called "Pearson Product Moment Correlation Coefficient". Person measurement " $r$ " is ranges between -1.0 and +1.0 and indicates the trend and power of the relationship between 2 variables.

- Simple regression models were generated to test the relationship of each of the independent variables with the dependent ones. In other terms, we have determined the relationship of each of the independent variable with the profitability: "ROE" and "ROA". For each model of independent variable with a dependent one we have analyzed the significance resulted from the ANOVA test, in order to determine if there is a relationship between the two variables, knowing that the significance level is 0.05 . When $\mathrm{p}$ value $<0.05$, there is a significant relationship between the independent and the dependent variables. In contrast, when $p$ value $>0.05$, we conclude that there is no significant relationship between the two variables.

- After the generation of the simple regression models, that assessed the relation of each independent variable on the dependent ones, we have performed multiple regressions in order to consider the effect of all independent variables together on the dependent ones. Multiple regression models for all the independent variables (Growth in loans, cost to income, capital adequacy and liquidity) and the first dependent variable "ROE", as well as for all the independent variables and the second dependent variable "ROA" were generated.

- Stepwise technique was used for multiple regression models, in order to eliminate the non-significant variables, thus resulting in the appropriate model including only the significant variables that affect the dependent ones.

- The generation of the regression models, resulted in the appropriate models for each of the dependent variables. However, an enhancement for the model was made by adding other external or control variables such as Year, Inflation GDP Deflator, GDP Growth and Real Interest Rate. These variables were added to assess the relationship of the internal variables and the profitability (being the dependent variable) in the presence of external variables other than the banks' internal performance determinants. The stepwise technique was also applied for these models, hence resulting in final models for ROE \& ROA that were tested later on.

- The final step for data analysis was the testing of serial correlation and heteroscedasticity to determine if the models issued are biased and not appropriate. The connection between interpretations of the same variable over certain period of time is determined by the serial correlation test named "Durbin-Watson" test for the independence of observations.

The heteroscedasticity tested the errors of the regression model in order to determine of their variance is constant. When this supposition is disrupted, we have an heteroscedasticity problem. The Breusch Pagan test was used to determine if there is heteroscedasticity.

\subsubsection{Model Specification}

The models studied are illustrated below:

$$
\begin{gathered}
R O E=\alpha 1+\beta 1(\text { Growth_Loans })+\beta 2(\text { Cost_Income })+\beta 3(\text { Capital_Adequacy })+\beta 4(\text { Liquidity })+\beta 5(\text { Year })+ \\
\beta 6(\text { GDP_Growth })+\beta 7(\text { Inflation_GDP_Def })+\beta 8(\text { Real_IR }) \\
R O A=\alpha 1+\beta 1(\text { Growth_Loans })+\beta 2(\text { Cost_Income })+\beta 3(\text { Capital_Adequacy })+\beta 4(\text { Liquidity })+\beta 5(\text { Year })+ \\
\beta 6(\text { GDP_Growth })+\beta 7(\text { Inflation_GDP_Def })+\beta 8(\text { Real_IR })
\end{gathered}
$$

Where,

$\alpha=$ intercept;

$\beta 1-\beta 8=$ Coefficients parameters;

Growth_Loans= Growth in loans of Lebanese banks at time $\mathrm{t}$;

Cost_Income $=$ Cost to income ratio or efficiency of Lebanese banks at time $t$;

Capital_Adequacy= Capital Adequacy ratio or capital quality of Lebanese banks at time t;

Liquidity $=$ Liquidity ratio of Lebanese banks at time $t$

GDP-Growth= GDP Growth in Lebanon at time t;

Inflation_GDP_Def=Inflation GDP Deflator rate at time t; 
Year= Year of financial performance;

Real_IR= Real Interest Rate at time t.

\subsubsection{Model Assumptions}

The following assumptions were tested to ensure that the data complies with the characteristics of a linear regression model:

Assumption\#1: The relationship between variables should be linear. The linear relationship is tested through creating a scatter plot where the dependent and independent variables are plotted against each other's and then allows to check linearity.

Assumption\#2: Observations should be independent. An easy method for checking the independence of observations is Durbin-Watson statistic performed through SPSS.

Assumption\#3: Homoscedasticity of should exist, which means that the variance of errors is constant. $\mathrm{E}\left(\mathrm{u}^{2} \mathrm{t}\right)=$ $\delta^{2} t$ : the variance of error is constant.

Assumption\#4: Arithmetical individuality of errors, which means no correlations between successive errors.

$\mathbf{E}\left(\mathbf{u t}, \mathbf{u t} \mathbf{t}^{\prime}\right)=\mathbf{0}$ if $\mathbf{t} \# \mathbf{t}$ '

An error at time $t$, does not affect the following errors.

\section{Findings and Analysis}

This section includes the examination of the study results in terms of: Multiple Regression, Stepwise method, Serial Correlation test and Breusch Pagan test (heteroscedasticity test).

Table 2. ANOVA independent variables \& ROE

\begin{tabular}{llccccc}
\hline \multicolumn{7}{c}{ ANOVA $^{\mathbf{a}}$} \\
\hline Model & & Sum of Squares & df & Mean Square & F & Sig. \\
\hline \multirow{3}{*}{1} & Regression & .002 & 4 & .000 & 4.100 & $.021^{\text {b }}$ \\
& Residual & .001 & 14 & .000 & & \\
& Total & .003 & 18 & & & \\
\hline
\end{tabular}

a. Dependent Variable: ROE

b. Predictors: (Constant), Liquidity, Growth_Loans, Capital_Adequacy, Cost_Income

Table 3. Coefficient of independent variables \& ROE

\begin{tabular}{|c|c|c|c|c|c|c|}
\hline \multicolumn{7}{|c|}{ Coefficients $^{\mathrm{a}}$} \\
\hline \multirow{2}{*}{\multicolumn{2}{|c|}{ Model }} & \multicolumn{2}{|c|}{ Unstandardized Coefficients } & \multirow{2}{*}{$\begin{array}{c}\text { Standardized Coefficients } \\
\text { Beta } \\
\end{array}$} & \multirow[t]{2}{*}{$\mathrm{t}$} & \multirow[t]{2}{*}{ Sig. } \\
\hline & & $\mathrm{B}$ & Std. Error & & & \\
\hline & (Constant) & .105 & .081 & & 1.294 & .216 \\
\hline & Growth_Loans & .064 & .037 & .476 & 1.738 & .104 \\
\hline & Cost_Income & -.034 & .099 & -.204 & -.344 & .736 \\
\hline & Capital_Adequacy & .103 & .221 & .259 & .463 & .651 \\
\hline & Liquidity & .017 & .016 & .322 & 1.105 & .288 \\
\hline
\end{tabular}

a. Dependent Variable: ROE

\subsection{Multiple Regression Models}

In this section we have prepared multiple regression models for all the independent variables (Growth in loans, cost to income, capital adequacy and liquidity) and the first dependent variable "ROE", as well as for all the independent variables and the second dependent variable "ROA".

4.1.1 Multiple Regression for ROE \& the Independent Variables

Table 3 shows that when all variables are together the significant of each one became less than 0.05 which means that there is no significant relationship between the ROE and all of the above variables.

A problem arisen in this model and is about variables selection. A determination must be made for the actual set of predictor variables used in the final regression model. Hence, the backward stepwise technique was applied. The main problem is the existence of variables that are not really necessary in the model.

The backward selection model considers all the variables and becomes to remove the variable that is the most 
non-significant. The process end when no non-significant variables are remaining.

The results of the backward stepwise for this model are illustrated below:

Table 4. Model summary independent variables \& ROE- Stepwise

\begin{tabular}{lcccc}
\hline \multicolumn{5}{c}{ Model Summary } \\
\hline Model & $\mathrm{R}$ & $\mathrm{R}$ Square & Adjusted R Square & Std. Error of the Estimate \\
\hline 1 & $.734^{\mathrm{a}}$ & .539 & .408 & .0099657 \\
2 & $.732^{\mathrm{b}}$ & .536 & .443 & .0096683 \\
3 & $.706^{\mathrm{c}}$ & .498 & .435 & .0097327 \\
4 & $.683^{\mathrm{d}}$ & .466 & .435 & .0097347 \\
\hline
\end{tabular}

a. Predictors: (Constant), Liquidity, Growth_Loans, Capital_Adequacy, Cost_Income

b. Predictors: (Constant), Liquidity, Growth_Loans, Capital_Adequacy

c. Predictors: (Constant), Growth_Loans, Capital_Adequacy

d. Predictors: (Constant), Growth_Loan

Table 5. Coefficient of independent variables \& ROE-Stepwise

\begin{tabular}{|c|c|c|c|c|c|c|}
\hline \multicolumn{7}{|c|}{ Coefficients $^{\mathrm{a}}$} \\
\hline \multirow[t]{2}{*}{ Model } & & \multicolumn{2}{|c|}{ Unstandardized Coefficients } & \multirow{2}{*}{$\begin{array}{c}\text { Standardized Coefficients } \\
\text { Beta } \\
\end{array}$} & \multirow[t]{2}{*}{$\mathrm{t}$} & \multirow[t]{2}{*}{ Sig } \\
\hline & & B & Std. Error & & & \\
\hline \multirow{5}{*}{1} & (Constant) & .105 & .081 & & 1.294 & .216 \\
\hline & Growth_Loans & .064 & .037 & .476 & 1.738 & .104 \\
\hline & Cost_Income & -.034 & .099 & -.204 & -.344 & .736 \\
\hline & Capital_Adequacy & .103 & .221 & .259 & .463 & .651 \\
\hline & Liquidity & .017 & .016 & .322 & 1.105 & .288 \\
\hline \multirow{4}{*}{2} & (Constant) & .078 & .020 & & 3.936 & .001 \\
\hline & Growth_Loans & .072 & .027 & .536 & 2.615 & .020 \\
\hline & Capital_Adequacy & .167 & .112 & .423 & 1.493 & .156 \\
\hline & Liquidity & .017 & .015 & .309 & 1.102 & .288 \\
\hline \multirow{3}{*}{3} & (Constant) & .098 & .008 & & 11.696 & .000 \\
\hline & Growth_Loans & .086 & .024 & .643 & 3.538 & .003 \\
\hline & Capital_Adequacy & .072 & .072 & .182 & 1.004 & .331 \\
\hline \multirow{2}{*}{4} & (Constant) & .105 & .003 & & 31.478 & .000 \\
\hline & Growth_Loans & .092 & .024 & .683 & 3.855 & .001 \\
\hline
\end{tabular}

a. Dependent Variable: ROE

The stepwise technique worked on eliminating the non-significant variables. We can notice that in the second model the cost_income variable was eliminated since as per model 1 the cost to income is the less significant variables $(\mathrm{Sig}=0.736)$. When we removed the cost to income variable the growth in loans became significant where sig $=0.02<0.05$.

Model 3 eliminated the liquidity variable since as per model 2, sig of liquidity $=0.288$ representing the highest value and the most far from the critical value 0.05 . After elimination of the liquidity variable the results shows that the capital adequacy remained non-significant with a value of $0.331>0.05$, and the only significant variable is the growth in loans. Hence, the final model for the ROE can be written as follows:

$$
R O E=0.105+0.092 \text { (Growth_Loans) }
$$

Every increase in growth in loans by $10 \%$ will result in an increase in ROE by $0.92 \%$.

4.1.2 Multiple Regression for ROA \& the Independent Variables

Table 6. Model summary independent variables \& ROA

\begin{tabular}{lcccc}
\hline \multicolumn{4}{c}{ Model Summary } \\
\hline Model & $\mathrm{R}$ & $\mathrm{R}$ Square & Adjusted R Square & Std. Error of the Estimate \\
\hline 1 & $.959^{\mathrm{a}}$ & .920 & .897 & .0005877 \\
\hline a. Predictors: (Constant), Liquidity, Growth Loans, Capital Adequacy, Cost Income & &
\end{tabular}


Table 7. ANOVA independent variables \& ROA

\begin{tabular}{|c|c|c|c|c|c|c|}
\hline \multicolumn{7}{|c|}{ ANOVA $^{a}$} \\
\hline Model & & Sum of Squares & $\mathrm{df}$ & Mean Square & $\mathrm{F}$ & Sig. \\
\hline \multirow{3}{*}{1} & Regression & .000 & 4 & .000 & 40.161 & $.000^{\mathrm{b}}$ \\
\hline & Residual & .000 & 14 & .000 & & \\
\hline & Total & .000 & 18 & & & \\
\hline
\end{tabular}

a. Dependent Variable: ROA

b. Predictors: (Constant), Liquidity, Growth_Loans, Capital_Adequacy, Cost_Income

Table 8. Coefficient of independent variables \& ROA

\begin{tabular}{|c|c|c|c|c|c|c|}
\hline \multicolumn{7}{|c|}{ Coefficients $^{\mathrm{a}}$} \\
\hline \multirow{2}{*}{\multicolumn{2}{|c|}{ Model }} & \multicolumn{2}{|c|}{ Unstandardized Coefficients } & \multirow{2}{*}{$\begin{array}{c}\text { Standardized Coefficients } \\
\text { Beta } \\
\end{array}$} & \multirow[t]{2}{*}{$\mathrm{t}$} & \multirow[t]{2}{*}{ Sig. } \\
\hline & & $\mathrm{B}$ & Std. Error & & & \\
\hline \multirow{5}{*}{1} & (Constant) & .017 & .005 & & 3.639 & .003 \\
\hline & Growth_Loans & .005 & .002 & .290 & 2.537 & .024 \\
\hline & Cost_Income & -.018 & .006 & -.744 & -3.004 & .009 \\
\hline & Capital_Adequacy & .006 & .013 & .112 & .479 & .639 \\
\hline & Liquidity & .001 & .001 & .119 & .981 & .343 \\
\hline
\end{tabular}

a. Dependent Variable: ROA

Table 6 shows that the adjusted R squared for this model is 0.897 , meaning that $89.7 \%$ of the deviation in ROA is caused by the deviation of the four variables.

Based on the table 38, we can notice that there is a significant relationship between the ROA and the growth in loans ( $\mathrm{Sig}=0.024<0.05$ ) and the Cost to Income ( $\mathrm{Sig}=0.009<0.05)$. In contrast, there is no significant relationship between ROA, capital adequacy and liquidity ( $\mathrm{Sig}=0.639 \& 0.343$ respectively).

The stepwise technique was also applied for the regression models related to ROA and the results are as follows:

Table 9. Model summary independent variables \& ROA-Stepwise

\begin{tabular}{lcccc}
\hline \multicolumn{5}{c}{ Model Summary } \\
\hline Model & $\mathrm{R}$ & R Square & Adjusted R Square & Std. Error of the Estimate \\
\hline 1 & $.959^{\mathrm{a}}$ & .920 & .897 & .0005877 \\
2 & $.958^{\mathrm{b}}$ & .919 & .902 & .0005724 \\
3 & $.956^{\mathrm{c}}$ & .914 & .903 & .0005692 \\
\hline
\end{tabular}

a. Predictors: (Constant), Liquidity, Growth_Loans, Capital_Adequacy, Cost_Income

b. Predictors: (Constant), Liquidity, Growth_Loans, Cost_Income

c. Predictors: (Constant), Growth_Loans, Cost_Income

Table 10. Coefficient of independent variables \& ROA-Stepwise

\begin{tabular}{|c|c|c|c|c|c|c|}
\hline \multicolumn{7}{|c|}{ Coefficientsa } \\
\hline \multirow[t]{2}{*}{ Model } & & \multicolumn{2}{|c|}{ Unstandardized Coefficients } & \multirow{2}{*}{$\begin{array}{c}\text { Standardized Coefficients } \\
\text { Beta } \\
\end{array}$} & \multirow[t]{2}{*}{$\mathrm{t}$} & \multirow[t]{2}{*}{ Sig. } \\
\hline & & $\mathrm{B}$ & Std. Error & & & \\
\hline \multirow{5}{*}{1} & (Constant) & .017 & .005 & & 3.639 & .003 \\
\hline & Growth_Loans & .005 & .002 & .290 & 2.537 & .024 \\
\hline & Cost_Income & -.018 & .006 & -.744 & -3.004 & .009 \\
\hline & Capital_Adequacy & .006 & .013 & .112 & .479 & 639 \\
\hline & Liquidity & .001 & .001 & .119 & .981 & .343 \\
\hline \multirow{4}{*}{2} & (Constant) & .020 & .001 & & 13.404 & .000 \\
\hline & Growth_Loans & .005 & .002 & .271 & 2.595 & .020 \\
\hline & Cost_Income & -.020 & .003 & -.846 & -6.711 & .000 \\
\hline & Liquidity & .001 & .001 & .103 & .905 & .380 \\
\hline \multirow{3}{*}{3} & (Constant) & .019 & .001 & & 15.856 & .000 \\
\hline & Growth_Loans & .006 & .002 & .328 & 3.977 & .001 \\
\hline & Cost_Income & -.018 & .002 & -.760 & -9.208 & .000 \\
\hline
\end{tabular}

a. Dependent Variable: ROA 
After application of the stepwise technique for the model, the capital adequacy factors was first eliminated since it is non-significant and has the most far value (0.639) from the critical value 0.05. After elimination of the capital adequacy variable, the results in model 2 shows that there is significant relation between ROA, growth in loans and cost to income, while there is no significant relation with liquidity ( $\mathrm{Sig}=0.380>0.05$ ).

The final model generated after the elimination of the last non-significant factor which is liquidity is illustrated as follows:

We can conclude from the two final models for ROA \& ROE the following:

$$
R O A=0.19+0.006 \text { (Growth_Loans) }-0.018 \text { (Cost_Income })
$$

- A positive relationship exists between ROE and growth in loans explained as follows: Every increase in growth in loans by $10 \%$ will result in an increase in ROE by $0.92 \%$.

- A positive relationship exists between ROA and growth in loans, however a negative significant relationship between ROA and cost to income explained as follows: Every increase in growth to loans by $10 \%$ will lead to an increase in ROA by $0.06 \%$ and every increase in cost to income by $10 \%$ will lead to a decrease in ROA by $0.18 \%$.

\subsubsection{Multiple Regression Model Including Additional External Factors}

Before the final step of our study which is testing the heteroscedasticity of residuals in order to determine efficiency and the stability of the regression model built, we have considered some external factors taking into consideration the internal ones in order to enhance the model.

A multiple regression followed by the stepwise technique was performed, knowing that the added external or control variables are: Lebanon GDP Growth, Lebanon Inflation Rate, Year and the Real Interest Rate.

The results are summarized as follows:

\subsubsection{Multiple Regressions for ROE}

Table 11. Model summary independent $\&$ additional variables $\&$ ROE

\begin{tabular}{lcccc}
\hline \multicolumn{5}{c}{ Model Summary } \\
\hline Model & $\mathrm{R}$ & $\mathrm{R}$ Square & Adjusted R Square & Std. Error of the Estimate \\
\hline 1 & $.951^{\mathrm{a}}$ & .905 & .830 & .0053473 \\
\hline a. Predictors: (Constant), Year, GDP_Growth, Inflation_GDP_Def, Growth_Loans, Liquidity, Capital_Adequacy, Cost_Income, Real_IR
\end{tabular}

Table 12. ANOVA independent \& additional variables \& ROE

\begin{tabular}{llccccc}
\hline \multicolumn{7}{c}{ ANOVA $^{\mathbf{a}}$} \\
\hline Model & & Sum of Squares & df & Mean Square & F & Sig. \\
\hline \multirow{3}{*}{1} & Regression & .003 & 8 & .000 & 11.948 & $.000^{\mathrm{b}}$ \\
& Residual & .000 & 10 & .000 & & \\
& Total & .003 & 18 & & & \\
\hline
\end{tabular}

a. Dependent Variable: ROE

Table 13. Coefficient of independent \& additional variables \& ROE

\begin{tabular}{|c|c|c|c|c|c|c|}
\hline \multicolumn{7}{|c|}{ Coefficients } \\
\hline \multirow{2}{*}{\multicolumn{2}{|c|}{ Model }} & \multicolumn{2}{|c|}{ Unstandardized Coefficients } & \multirow{2}{*}{$\begin{array}{c}\text { Standardized Coefficients } \\
\text { Beta } \\
\end{array}$} & \multirow[t]{2}{*}{$\mathrm{t}$} & \multirow[t]{2}{*}{ Sig. } \\
\hline & & $\mathrm{B}$ & Std. Error & & & \\
\hline \multirow{9}{*}{1} & (Constant) & 14.147 & 2.638 & & 5.363 & .000 \\
\hline & Growth_Loans & -.022 & .026 & -.162 & -.848 & .416 \\
\hline & Cost_Income & -.213 & .063 & -1.274 & -3.391 & .007 \\
\hline & Capital_Adequacy & .554 & .146 & 1.398 & 3.796 & .004 \\
\hline & Liquidity & -.019 & .013 & -.350 & -1.402 & .191 \\
\hline & GDP_Growth & .165 & .083 & .421 & 1.980 & .076 \\
\hline & Inflation_GDP_Def & -.129 & .099 & -.336 & -1.308 & .220 \\
\hline & Real_IR & -.164 & .083 & -.759 & -1.973 & .077 \\
\hline & Year & -.007 & .001 & -3.019 & -5.318 & .000 \\
\hline
\end{tabular}


After adding the above stated variables, the adjusted $\mathrm{R}$ squared as per table 11 is 0.830 indicating that $83 \%$ of the variation in ROE is explained by the variation of all of the above independent factors.

Table 13 indicates the following:

- There is no significant relationship between the growth in loans and ROE ( $\mathrm{Sig}=0.416>0.05)$

- There is significant relationship between the cost_to_income and the ROE $(\operatorname{Sig}=0.007<0.05)$

- There is a significant relationship between the capital adequacy and ROE (Sig=0.004<0.05)

- No significant relation exists between the liquidity and ROE ( $\mathrm{Sig}=0.191>0.05$ )

- There is no significant relationship between the GDP growth and ROE ( $\mathrm{Sig}=0.076>0.05$ )

- No significant relationship exists between the inflation rate and ROE ( $\mathrm{Sig}=0.220>0.05)$

- No significant relationship exists between the real interest rate and ROE ( $\mathrm{Sig}=0.077>0.05)$

- No significant relationship exists between the year and the ROE ( $\mathrm{Sig}=0.00<0.05)$

For elimination of non-significant variables, the stepwise backward technique was applied and resulted in the following:

Table 14. Model summary independent \& additional variables \& ROE- Stepwise

\begin{tabular}{|c|c|c|c|c|}
\hline \multicolumn{5}{|c|}{ Model Summary } \\
\hline Model & $\mathrm{R}$ & R Square & Adjusted R Square & Std. Error of the Estimate \\
\hline 1 & $.951^{\mathrm{a}}$ & .905 & .830 & .0053473 \\
\hline 2 & $.948^{\mathrm{b}}$ & .898 & .834 & .0052786 \\
\hline 3 & $.942^{\mathrm{c}}$ & .887 & .831 & .0053242 \\
\hline 4 & $.938^{\mathrm{d}}$ & .879 & .833 & .0052915 \\
\hline 5 & $.929^{\mathrm{e}}$ & .863 & .824 & .0054312 \\
\hline \multicolumn{5}{|c|}{ a. Predictors: (Constant), Year, GDP_Growth, Inflation_GDP_Def, Growth_Loans, Liquidity, Capital_Adequacy, Cost_Income, Real_I } \\
\hline \multicolumn{5}{|c|}{ b. Predictors: (Constant), Year, GDP_Growth, Inflation_GDP_Def, Liquidity, Capital_Adequacy, Cost_Income, Real_IR } \\
\hline \multicolumn{5}{|c|}{ c. Predictors: (Constant), Year, GDP_Growth, Liquidity, Capital_Adequacy, Cost_Income, Real_IR } \\
\hline \multicolumn{5}{|c|}{ d. Predictors: (Constant), Year, GDP_Growth, Capital_Adequacy, Cost_Income, Real_IR } \\
\hline \\
\hline
\end{tabular}

Table 15. Coefficient of independent \& additional variables \& ROE-Stepwise

\begin{tabular}{|c|c|c|c|c|c|c|}
\hline \multicolumn{7}{|c|}{ Coefficients $^{\mathrm{a}}$} \\
\hline \multirow{2}{*}{\multicolumn{2}{|c|}{ Model }} & \multicolumn{2}{|c|}{ Unstandardized Coefficients } & \multirow{2}{*}{$\frac{\text { Standardized Coefficients }}{\text { Beta }}$} & \multirow[t]{2}{*}{$\mathrm{t}$} & \multirow[t]{2}{*}{ Sig. } \\
\hline & & $\mathrm{B}$ & Std. Error & & & \\
\hline \multirow{9}{*}{1} & (Constant) & 14.147 & 2.638 & & 5.363 & .000 \\
\hline & Growth_Loans & -.022 & .026 & -.162 & -.848 & .416 \\
\hline & Cost_Income & -.213 & .063 & -1.274 & -3.391 & .007 \\
\hline & Capital_Adequacy & .554 & .146 & 1.398 & 3.796 & .004 \\
\hline & Liquidity & -.019 & .013 & -.350 & -1.402 & .191 \\
\hline & GDP_Growth & .165 & .083 & .421 & 1.980 & .076 \\
\hline & Inflation_GDP_Def & -.129 & .099 & -.336 & -1.308 & .220 \\
\hline & Real_IR & -.164 & .083 & -.759 & -1.973 & .077 \\
\hline & Year & -.007 & .001 & -3.019 & -5.318 & .000 \\
\hline \multirow{8}{*}{2} & (Constant) & 12.782 & 2.063 & & 6.196 & .000 \\
\hline & Cost_Income & -.180 & .049 & -1.077 & -3.695 & .004 \\
\hline & Capital_Adequacy & .537 & .143 & 1.355 & 3.763 & .003 \\
\hline & Liquidity & -.016 & .013 & -.300 & -1.253 & .236 \\
\hline & GDP_Growth & .132 & .073 & .337 & 1.814 & .097 \\
\hline & Inflation_GDP_Def & -.101 & .092 & -.262 & -1.099 & .295 \\
\hline & Real_IR & -.139 & .077 & -.644 & -1.813 & .097 \\
\hline & Year & $\underline{-.006}$ & .001 & $\underline{-2.728}$ & $\underline{-6.107}$ & .000 \\
\hline \multirow{7}{*}{3} & (Constant) & 11.414 & 1.659 & & 6.879 & .000 \\
\hline & Cost_Income & -.189 & .048 & -1.132 & -3.911 & .002 \\
\hline & Capital_Adequacy & .493 & .138 & 1.245 & 3.568 & .004 \\
\hline & Liquidity & -.011 & .012 & -.207 & -.917 & .377 \\
\hline & GDP_Growth & .112 & .071 & .286 & 1.577 & .141 \\
\hline & Real_IR & -.066 & .039 & -.307 & -1.701 & .115 \\
\hline & $\underline{\text { Year }}$ & -.006 & .001 & -2.432 & -6.764 & .000 \\
\hline
\end{tabular}




\begin{tabular}{llccccc}
\hline & (Constant) & 10.699 & 1.456 & & 7.348 & .000 \\
& Cost_Income & -.191 & .048 & -1.143 & -3.977 & .002 \\
Capital_Adequacy & .482 & .137 & 1.217 & 3.524 & .004 \\
GDP_Growth & .066 & .050 & .169 & 1.323 & .209 \\
& Real_IR & -.070 & .038 & -.322 & -1.807 & .094 \\
& Year & -.005 & .001 & -2.278 & -7.210 & .000 \\
& (Constant) & 11.174 & 1.448 & -1.268 & -4.716 & .000 \\
& Cost_Income & -.212 & .047 & 1.111 & 3.222 & .000 \\
& Capital_Adequacy & .440 & .137 & -.435 & -2.700 & .017 \\
\\
Real_IR & -.094 & .035 & -2.377 & -7.539 & .000 \\
\hline
\end{tabular}

a. Dependent Variable: ROE

Based on table 15, the stepwise technique eliminated the most non-significant factor in model 1 which is growth in loans (having the most far sig value $=0.416$ from the critical value).

The same was made for each model after the elimination of the non-significant variables from the most to the least.

The final model includes only 4 variables out of 8 which are: Cost to Income, Capital Adequacy, Real Interest Rate, and Year.

The final model for ROE after intervention of external or control factors is:

$$
R O E=11.174-0.212(\text { Cost_Income })+0.440(\text { Capital_Adequacy })-0.094(\text { Real_IR })-0.005(\text { Year })
$$

\subsubsection{Multiple Regressions for ROA}

Table 16. Model Summary Independent \& Additional Variables \& ROA

\begin{tabular}{lcc}
\hline \multicolumn{2}{c}{ Model Summary } \\
\hline Model & $\mathrm{R}$ & $\mathrm{R}$ Square \\
\hline 1 & $.983^{\mathrm{a}}$ & .967 \\
\hline a. Predictors: (Constant), Year, GDP Growth, Inflation GDP Def, Growth_Loans, Liquidity, Capital_Adequacy, Cost_Income, Real
\end{tabular}

a. Predictors: (Constant), Year, GDP_Growth, Inflation_GDP_Def, Growth_Loans, Liquidity, Capital_Adequacy, Cost_Income, Real_IR

Table 17. ANOVA independent \& additional variables \& ROA

\begin{tabular}{clccccc}
\hline \multicolumn{5}{c}{ ANOVA $^{\mathbf{a}}$} & & \\
\hline Model & & Sum of Squares & df & Mean Square & F & Sig. \\
\hline \multirow{3}{*}{1} & Regression & .000 & 8 & .000 & 36.774 & $.000^{\mathrm{b}}$ \\
& Residual & .000 & 10 & .000 & & \\
& Total & .000 & 18 & & & \\
\hline
\end{tabular}

a. Dependent Variable: ROA

b. Predictors: (Constant), Year, GDP_Growth, Inflation_GDP_Def, Growth_Loans, Liquidity, Capital_Adequacy, Cost_Income, Real_IR

Table 18. Coefficient of independent \& additional variables \& ROA

\begin{tabular}{|c|c|c|c|c|c|}
\hline \multicolumn{6}{|c|}{ Coefficients $^{\mathrm{a}}$} \\
\hline \multirow[t]{2}{*}{ Model } & \multicolumn{2}{|c|}{ Unstandardized Coefficients } & \multirow{2}{*}{$\begin{array}{c}\text { Standardized Coefficients } \\
\text { Beta }\end{array}$} & \multirow[t]{2}{*}{$\mathrm{t}$} & \multirow[t]{2}{*}{ Sig. } \\
\hline & $\mathrm{B}$ & Std. Error & & & \\
\hline (Constant) & .442 & .220 & & 2.011 & .072 \\
\hline Growth_Loans & .002 & .002 & .124 & 1.101 & .297 \\
\hline Cost_Income & -.024 & .005 & -1.017 & -4.594 & .001 \\
\hline Capital_Adequacy & .023 & .012 & .411 & 1.896 & .087 \\
\hline Liquidity & .000 & .001 & -.052 & -.351 & .733 \\
\hline GDP_Growth & .007 & .007 & .124 & .995 & .343 \\
\hline Inflation_GDP_Def & .010 & .008 & .179 & 1.182 & .264 \\
\hline Real_IR & .003 & .007 & .087 & .386 & .707 \\
\hline Year & .000 & .000 & -.646 & -1.933 & .082 \\
\hline
\end{tabular}

a. Dependent Variable: ROA

The adjusted $\mathrm{R}$ squared in table 16 indicates that $94.1 \%$ of the variation in ROA is explained by the variation of the 8 independent variables.

Table 18 indicates that a significant relationship exists between ROA \& Cost to Income only since 
$\mathrm{Sig}=0.01<0.05$. However, there is no significant relationship between ROA and all the other variables since their related sig $>0.05$.

Same as above the stepwise backward technique was applied and resulted in the following:

Table 19. Model summary independent $\&$ additional variables $\&$ ROA- Stepwise

\begin{tabular}{|c|c|c|c|c|}
\hline \multicolumn{5}{|c|}{ Model Summary } \\
\hline Model & $\mathrm{R}$ & R Square & Adjusted R Square & Std. Error of the Estimate \\
\hline 1 & $.983^{\mathrm{a}}$ & .967 & .941 & .0004453 \\
\hline 2 & $.983^{\mathrm{b}}$ & .967 & .946 & .0004272 \\
\hline 3 & $.983^{\mathrm{c}}$ & .966 & .949 & .0004146 \\
\hline 4 & $.981^{\mathrm{d}}$ & .962 & .948 & .0004187 \\
\hline \multicolumn{5}{|c|}{ a. Predictors: (Constant), Year, GDP_Growth, Inflation_GDP_Def, Growth_Loans, Liquidity, Capital_Adequacy, Cost_Income, Real_IR } \\
\hline \\
\hline \multicolumn{5}{|c|}{ c. Predictors: (Constant), Year, GDP_Growth, Inflation_GDP_Def, Growth_Loans, Capital_Adequacy, Cost_Income } \\
\hline
\end{tabular}

Table 20. Coefficient of independent \& additional variables \& ROA-Stepwise

\begin{tabular}{|c|c|c|c|c|c|c|}
\hline \multicolumn{7}{|c|}{ Coefficients $^{\mathrm{a}}$} \\
\hline \multirow[t]{2}{*}{ Model } & & \multicolumn{2}{|c|}{ Unstandardized Coefficients } & \multirow{2}{*}{$\begin{array}{c}\text { Standardized Coefficients } \\
\text { Beta }\end{array}$} & \multirow[t]{2}{*}{$\mathrm{t}$} & \multirow[t]{2}{*}{ Sig. } \\
\hline & & B & Std. Error & & & \\
\hline \multirow{9}{*}{1} & (Constant) & .442 & .220 & & 2.011 & .072 \\
\hline & Growth_Loans & .002 & .002 & .124 & 1.101 & .297 \\
\hline & Cost_Income & -.024 & .005 & -1.017 & -4.594 & .001 \\
\hline & Capital_Adequacy & .023 & .012 & .411 & 1.896 & .087 \\
\hline & Liquidity & .000 & .001 & -.052 & -.351 & .733 \\
\hline & GDP_Growth & .007 & .007 & .124 & .995 & .343 \\
\hline & Inflation_GDP_Def & .010 & .008 & .179 & 1.182 & .264 \\
\hline & Real_IR & .003 & .007 & .087 & .386 & .707 \\
\hline & Year & .000 & .000 & -.646 & -1.933 & .082 \\
\hline \multirow{8}{*}{2} & (Constant) & .397 & .172 & & 2.308 & .041 \\
\hline & Growth_Loans & .003 & .002 & .133 & 1.269 & .231 \\
\hline & Cost_Income & -.024 & .005 & -1.011 & -4.775 & .001 \\
\hline & Capital_Adequacy & .022 & .011 & .396 & 1.943 & .078 \\
\hline & GDP_Growth & .005 & .004 & .092 & 1.135 & .281 \\
\hline & Inflation_GDP_Def & .011 & .007 & .200 & 1.507 & .160 \\
\hline & Real_IR & .003 & .006 & .113 & .548 & .594 \\
\hline & Year & .000 & .000 & -.579 & -2.208 & .049 \\
\hline \multirow{7}{*}{3} & (Constant) & .463 & .119 & & 3.888 & .002 \\
\hline & Growth_Loans & .002 & .002 & .116 & 1.193 & .256 \\
\hline & Cost_Income & -.024 & .005 & -1.014 & -4.932 & .000 \\
\hline & Capital_Adequacy & .024 & .010 & .435 & 2.348 & .037 \\
\hline & GDP_Growth & .005 & .004 & .088 & 1.123 & .283 \\
\hline & Inflation_GDP_Def & .007 & .003 & .137 & 2.131 & .054 \\
\hline & Year & .000 & .000 & -.679 & -3.753 & .003 \\
\hline \multirow{6}{*}{4} & (Constant) & .431 & .117 & & 3.690 & .003 \\
\hline & Growth_Loans & .003 & .002 & .170 & 1.987 & .068 \\
\hline & Cost_Income & -.024 & .005 & -1.002 & -4.834 & .000 \\
\hline & Capital_Adequacy & .021 & .010 & .375 & 2.092 & .057 \\
\hline & Inflation_GDP_Def & .009 & .003 & .164 & 2.729 & .017 \\
\hline & Year & .000 & .000 & -.630 & -3.552 & .004 \\
\hline
\end{tabular}

a. Dependent Variable: ROA

As described in the above models, the stepwise technique eliminated the non-significant variable from the most to the least and the results show that the significant variables for this model are: Growth in loans, Cost to income, Capital adequacy, inflation GDP deflator rate and year.

The final model for ROA can be written as follows:

$$
\begin{gathered}
R O A=0.431+0.003(\text { Growth_Loans })-0.024(\text { Cost_Income })+0.021(\text { Capital Adequacy })+0.009 \\
\text { (Inflation_GDP_Def })+0.000(\text { Year })
\end{gathered}
$$

The final models are generated; however a serial correlation and heteroscedasticity tests should be applied to these final models. 
Serial correlation test is used to determine the relation between a variable and a trailed version of this one over several time intervals. Correlation is also known as auto-correlation.

Heteroscedasticity is very important in the application of regression analysis.

The two tests will be described in details in the section below

\subsubsection{Serial Correlation \& Heteroscedasticity Test}

\subsubsection{Serial Correlation}

The relation between the same factor's observations of a period is determined by the serial correlation test. So, we can say that Durbin-Watson test the independence of observations.

When the serial correlation is 0 , this means no correlation exists and the observations are independent from each other's.

When the correlation slopes to 1 , this means that the observations are dependent and correlation exists.

Using Durbin Watson test, serial correlation can be determined. The correlation can be either negative or positive.

- If $\mathrm{d}=0 \rightarrow$ Positive Serial Correlation

- If $\mathrm{d}=4 \rightarrow$ Negative Serial Correlation

- If $\mathrm{d}=2 \rightarrow$ No Serial Correlation

Refer to the below testing of auto-correlation for ROE and ROA models.

\subsection{ROA}

Table 21. Serial correlation ROA

\begin{tabular}{lccccc}
\hline \multicolumn{5}{c}{ Model Summary $^{\mathbf{b}}$} \\
\hline Model & $\mathrm{R}$ & R Square & Adjusted R Square & Std. Error of the Estimate & Durbin-Watson \\
\hline 1 & $.981^{\mathrm{a}}$ & .962 & .948 & .0004187 & 1.434 \\
\hline a. Predictors: (Constant), Year, Growth_Loans, Inflation_GDP_Def, Capital_Adequacy, Cost_Income \\
b. Dependent Variable: ROA
\end{tabular}

$\mathrm{DW}=1.434$

The null Hypothesis and the one-sided alternative hypothesis of no positive serial correlation are given below:

H0: p equal to $0 \rightarrow$ No positive serial correlation

$\mathrm{H} 1: \mathrm{p}>0 \rightarrow$ Positive serial correlation

Conditions:

If $\mathrm{d}<\mathrm{d}(\mathrm{L})$ Reject $\mathrm{H} 0$

If $\mathrm{d}>\mathrm{d}(\mathrm{U})$ Do not reject $\mathrm{H} 0$

If $\mathrm{d}(\mathrm{L})<=\mathrm{d}<=\mathrm{d}(\mathrm{U})$ Inconclusive

For this model, where $\mathrm{n}=19$ (referring to the number of observations) and $\mathrm{K}=5$ (referring to the number of variables) we can determine $\mathrm{d}(\mathrm{U})$ and $\mathrm{d}(\mathrm{L})$ for the Durbin Watson statistical table as follows:

$\mathrm{DL}=0.75 ; \mathrm{DU}=2.02$

As per table 51, DW= 1.434, it falls between DL \& DU which means that the test is inconclusive. However, the value is closer to DU, hence it is most probably that there no positive serial correlation between the errors of the model.

\subsection{ROE}

Table 22. Serial correlation ROE

\begin{tabular}{|c|c|c|c|c|c|}
\hline & & & Model Summary & & \\
\hline Model & $\mathrm{R}$ & R Square & Adjusted R Square & Std. Error of the Estimate & Durbin-Watson \\
\hline 1 & $.929^{\mathrm{a}}$ & .863 & .824 & .0054312 & 1.818 \\
\hline
\end{tabular}


As explained above, the same steps are applied to determine if there is a correlation between the errors of ROE model.

In this model, $\mathrm{n}=19$ and $\mathrm{K}=4$, hence:

$\mathrm{DL}=0.86 ; \mathrm{DU}=1.85$

$\mathrm{DW}=1.818$, it falls between DL \& $\mathrm{DU} \rightarrow$ Test is inconclusive.

However, the value is closer to 1.85 , therefore it is most probably that we do not reject $\mathrm{H} 0$, which means that there is no positive correlation between the errors of this model.

\subsubsection{Heteroscedasticity}

From the assumptions about errors in the OLS is the same variance of errors. This is known as homoscedasticity which means that the variance of errors is constant. In case of violation of this assumption, we have a problem called heteroscedasticity. The data tested should agree with the assumption of homoscedasticity. $E\left(u^{2} t=6^{2} t\right)$ : the variance of error is constant.

We have used the Breusch Pagan test for testing heteroscedasticity. The test statistic here is $\mathrm{NR}^{2}$ or the sample size $(\mathrm{N})$ times the unadjusted $\mathrm{R}^{2}$.

\subsection{ROA}

Table 23. Heteroscedasticity ROA

\begin{tabular}{lccccc}
\hline \multicolumn{5}{c}{ Model Summary $^{\mathbf{b}}$} \\
\hline Model & $\mathrm{R}$ & $\mathrm{R}$ Square & Adjusted R Square & Std. Error of the Estimate & Durbin-Watson \\
\hline 1 & $.646^{\mathbf{a}}$ & .418 & .194 & .00000 & 2.569 \\
\hline a. Predictors: (Constant), Year, Growth_Loans, Inflation_GDP_Def, Capital_Adequacy, Cost_Income \\
b. Dependent Variable: RES2_ROA
\end{tabular}

The null and alternative hypotheses are:

$H_{0}: \alpha_{1}=\alpha_{2}=0$

$H_{A}: H_{0}$ is false

The null hypothesis is homoscedasticity, because if $\alpha_{1}=\alpha_{2}=0$, then the variance equals $\alpha_{0}$, which is a constant. The test statistic here is $N R^{2}$,

$\mathrm{N}=19, \mathrm{R}^{2}=0.418 \rightarrow \mathrm{NR}^{2}=(19 * 0.418)=7.942$

Based on the chi square table, the critical chi-square value (for $\mathrm{k}=5$ degrees of freedom, at $5 \%$ level of significance) is 23.7 .

Since $\mathrm{NR}^{2}$ is lower than the critical value $(7.94<11.07)$ we can conclude that there is no heteroscedasticity.

\subsection{ROE}

Table 24. Heteroscedasticity ROE

\begin{tabular}{lcccc}
\hline \multicolumn{4}{c}{ Model Summary $^{\mathbf{b}}$} \\
\hline Model & $\mathrm{R}$ & $\mathrm{R}$ Square & Adjusted R Square & Std. Error of the Estimate \\
\hline 1 & $.523^{\text {a }}$ & .273 & .066 & .00003 \\
\hline $\begin{array}{l}\text { a. Predictors: (Constant), Year, Real_IR, Cost_Income, Capital_Adequacy } \\
\text { b. Dependent Variable: RES2_ROE }\end{array}$
\end{tabular}

$\mathrm{N}=19, \mathrm{R}^{2}=0.418 \rightarrow \mathrm{NR}^{2}=(19 * 0.273)=5.187$

Based on the chi square table, the critical chi-square value (for $k=4$ degrees of freedom, at $5 \%$ level of significance) is 9.49 .

Since $\mathrm{NR}^{2}$ is lower than the critical value $(5.18<9.49)$ we can conclude that there is no heteroscedasticity.

We can conclude that the two models generated are appropriate with no heteroscedasticity problem and probably with independent observations.

\section{Conclusion \& Recommendation}

The Banking Sector in Lebanon significantly influences Lebanon's economy, so assessing the performance of the 
Lebanese Banking Sector is very essential. There are many internal and external factors that affect banks performance measured in terms of Return on Equity "ROE", Return on Assets "ROA" and Net Interest Margin "NIM".

This study has employed four internal factors to assess their relationship with profitability determined by the ROE \& ROA. These internal factors are: Capital Adequacy, Liquidity, Efficiency and Loans Growth.

However the study was not limited to these factors only, it took into consideration the intervention of external or macroeconomic factors that are out of the banking sector control. The macroeconomic factors intervened in our study were: GDP Growth, Inflation GDP Deflator Rate \& Real Interest Rate.

The study revealed that profitability is affected by capital adequacy, efficiency, and assets quality or in other terms credit growth, while there is no relationship between liquidity and profitability. This result represents the effect of internal factors only, however the study also resulted in a relationship between profitability and real interest rate, inflation GDP deflator rate and time evolution, but no relationship between GDP growth and profitability.

After the analysis performed for all Lebanese banks among 19 observations covering the period from 1999 till 2017 through regression models, without taking into consideration any macroeconomic factor it was verified that profitability of Lebanese Banks is significantly influenced by the efficiency of its management and the growth in loans, where the two models generated showed that Return on Equity is positively related to growth in loans (Every increase in growth in loans by $10 \%$ will result in an increase in ROE by $0.92 \%$ ), while Return on Assets is positively related to growth in loans and negatively related to efficiency (Every increase in growth to loans by $10 \%$ will lead to an increase in ROA by $0.06 \%$ and every increase in cost to income by $10 \%$ will lead to a decrease in ROA by $0.18 \%$ ).

However, after intervention of external factors the profitability of Lebanese banks will be mainly affected by growth in loans, capital adequacy, efficiency, real interest rate, and Inflation GDP deflator rate as well as time evolution. The results of the regression models generated for internal and external factors indicate that Return on Equity is positively related to Capital Adequacy, while negatively related to efficiency, real interest rate and time evolution, and Return on Assets is positively related to growth in loans, capital adequacy \& inflation GDP deflator rate, while negatively related to efficiency.

We can conclude that profitability of banks is not based on maintaining high liquid assets; rather it is about capital adequacy, efficiency and loans growth.

This does not mean that liquidity does not have an effect on profitability at all, but it indicates that it has lower effect on the performance of Lebanese Banks for the period studied. The study also shows that the performance of Lebanese Banks is based more on the internal factors than the external ones since from the two models generated for ROE and ROA we can notice a very non-significant coefficient of relation between profitability and external factors.

We can recommend Lebanese Banks to improve their capital structure as well as to contribute for loan growth being positively related to profitability. So, the enhancement of banks' internal factors will lead to higher profitability.

For future researches, this study can be extending to cover longer periods as well as more internal and external factors. There are many other factors influencing banks' profitability, especially in Lebanon. For example, in the recent years the Lebanese Banks entered into swap operations with the central bank of Lebanon. BDL launched a financial engineering program where most Lebanese banks can borrow LBP at $2 \%$ and reinvest the proceeds in TBs/CDs from the primary and secondary market. In parallel, the bank is required to place USD Time Deposits at preferential rates. Banks earned significant gain from such operations and this significantly influenced their profitability.

So, we can conclude that with time evolution, the determinants of banks' profitability can change and the assessment of banks performance must be performed annually in order to keep an understanding on the main determinants of profitability and improve the factors leading to higher profit.

\section{References}

Anbar, A., \& Deger, A. (2011). Bank specific and macroeconomic determinants of commercial bank profitability: Empirical evidence from Turkey.

Athanasoglou, P. P., Sophocles, N. B., \& Matthaios, D. D. (2008). Bank-specific, industry-specific and macroeconomic determinants of bank profitability. Journal of International Financial Markets, Institutions 
and Money, 18(2), 121-136. https://doi.org/10.1016/j.intfin.2006.07.001

Bashir, A. H. M. (2003). Determinants of profitability in Islamic banks: Some evidence from the Middle East.

Flamini, V. et al. (2009). The Determinants of Commercial Bank Profitability in Su Saharan Africa. IMF Working Papers WP/09/15. https://doi.org/10.5089/9781451871623.001

Haslem, A. J. (2003). A Statistical Analysis of Member Bank Profitability Differences. Banking Journal. Accessed via the JSTOR Academic Database.

Hassan, Al T., \& Hussein, A. (2006). The determinants of the UAE commercial banks' performance: a comparison of the national and foreign banks. Journal of Transnational Management, 10(4), 35-47. https://doi.org/10.1300/J482v10n04_03

Hassan, M. K., \& Bashir, A. H. M. (2003, December). Determinants of Islamic banking profitability. In 10th ERF annual conference, Morocco (Vol. 7).

Ho, C. T., \& Zhu, D. S. (2004). Performance measurement of Taiwan's commercial banks. International Journal of Productivity and Performance Management, 53(5), 425-434. https://doi.org/10.1108/17410400410545897

Ho, T., \& Saunders, A. (1981). The Determinants of Bank Interest Margins: Theory and Empirical Evidence. Journal of Financial and Quantitative Analysis, 16, 581-600. https://doi.org/10.2307/2330377

Kumar, S., \& Gulati, R. (2009). Measuring efficiency, effectiveness and performance of Indian public sector banks. International Journal of Productivity and Performance Management, 59(1), 51-74. https://doi.org/10.1108/17410401011006112

Lin, X., \& Zhang, Y. (2009). Bank ownership reform and bank performance in China. Journal of Banking \& Finance, 33(1), 20-29. https://doi.org/10.1016/j.jbankfin.2006.11.022

Ongore, V. O., \& Gemechu, B. K. (2013). Determinants of financial performance of commercial banks in Kenya. International Journal of Economics and Financial Issues, 3(1), 237-252.

Trujilo-Ponce, A. (2013). What Determines the Profitability of banks from Spain? Working Paper, Department of Business Administration, Pablo de Qlavide University.

Vong, A., \& Hoi, S. (2009). Determinants of Bank Profitability in Macao. Faculty of Business Administration, University of Macau.

Wen, W. (2010). Ownership Structure and Banking Performance: New Evidence in China. Universitat Autònoma de Barcelona Departament D'economia de L'empresa, 2010.

\section{Websites}

http://www.bankdata.com/

http://libguides.library.cityu.edu.hk/thes/websites

www.researchgate.net/

http://www.abl.org.lb/index.aspx?pageid=9

http://aub.edu.lb.libguides.com/c.php?g=276425\&p=1843414

http://dspace.mit.edu/handle/1721.1/7582

https://scholar.google.com.hk/

http://pqdtopen.proquest.com/search.html

\section{Copyrights}

Copyright for this article is retained by the author(s), with first publication rights granted to the journal.

This is an open-access article distributed under the terms and conditions of the Creative Commons Attribution license (http://creativecommons.org/licenses/by/4.0/). 